\title{
Par Pond Vegetation Status Summer 1995 - Summary
}

by

H. E. Mackey

Westinghouse Savannah River Company

Savannah River Site

Aiken, South Carolina 29808

R. S. Riley

This paper was prepared in connection with work done under the above contract number with the U. S. Department of Energy. By acceptance of this paper, the publisher and/or recipient acknowledges the U.S. Government's right to retain a nonexclusive, royalty-free license in and to any copyright covering this paper, along with the right to reproduce and to authorize others to reproduce all or part of the copyrighted paper. 
WSRC-RP-95-1046

\section{Par Pond Vegetation Status Summer 1995-Summary}

Halkard E. Mackey, Jr. and R. S. Riley

Westinghouse Savannah River Company

Savannah River Technology Center

Environmental Sciences Section

Aiken, SC 29808

January 1996

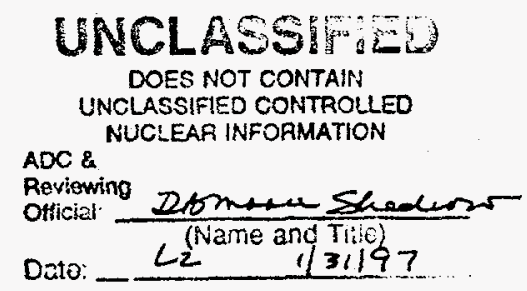

The information contained in this report was developed during the course of work with the U.S. Department of Energy under Contract No. DE-AC09-89SR18035. 


\section{DISCLAMMER}

This report was prepared as an account of work sponsored by an agency of the United States Government. Neither the United States Government nor any agency thereof, nor any of their employees, makes any warranty, express or implied, or assumes any legal liability or. responsibility for the accuracy, completeness, or usefulness of any information, apparatus, product, or process disclosed, or represents that its use would not infringe privately owned rights. Reference herein to any specific commercial product, process, or service by trade name, trademark, manufacturer, or otherwise does not necessarily constitute or imply its endorsement, recommendation, or favoring by the United States Government ar any agency thereof. The views and opinions of authors expressed herein do not necessarily state or reflect those of the United States Government or any agency thereof.

This report has been reproduced directly from the best available copy.

Available to DOE and DOE contractors from the Office of Scientific and Technical Information, P.O. Box 62, Oak Ridge, TN 37831; prices available from (615) 576-8401.

Available to the public from the National Technical. Information Service, U.S. Department of Commerce, 5285 Port Royal Road, Springfield, VA 22161. 


\section{DISCLAMIER}

Portions of this document may be illegible in electronic image products. Images are produced from the best available original document. 


\section{Table of Contents}

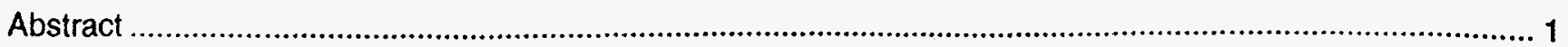

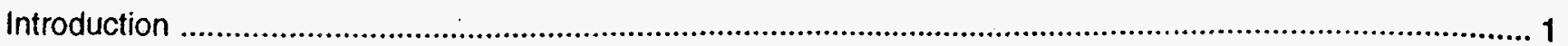

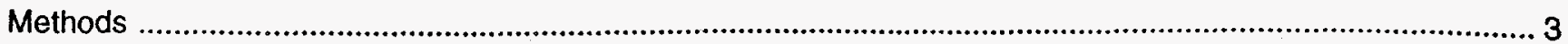

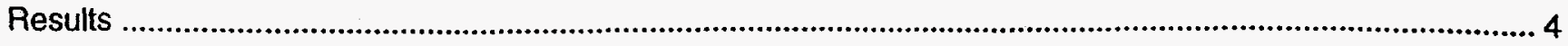

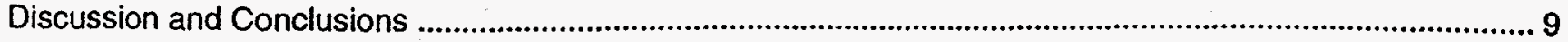

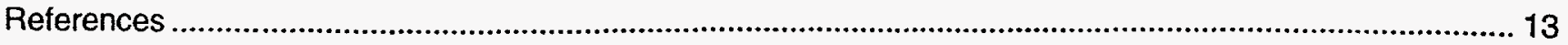

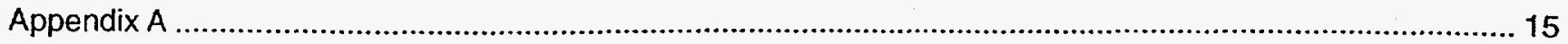




\section{List of Figures}

Figure 1.

Map of Par Pond marked with locations of transects

Figure 2.

Rate of Par Pond refill during winter and early spring 1995

Figure 3.

Water level changes following refill of Par Pond in 1995 5

Figure 4.

Woody species percent occurrence at the inner zones of

Par Pond transects. June, July, September, and October 1995

Figure 5.

Woody species percent occurrence at the outer zones of

Par Pond transects. June, July, September, and October 1995

Figure 6.

Herbaceous species percent occurrence at the inner zones of

Par Pond transects. June, July, September, and October 1995

Figure 7.

Herbaceous species percent occurrence at the outer zones of

Par Pond transects. June, July, September, and October 1995

Figure 8.

Herbaceous species percent cover at the inner zones of

Par Pond transects. June, July, September, and October 1995

Figure 9.

Herbaceous species percent cover at the outer zones of

Par Pond transects. June, July, September, and October 1995

Figure 10.

Trends in macrophyte growth at the inner zones of

Par Pond transects. June, July, September, and October 1995 10

Figure 11.

Trends in macrophyte growth at the outer zones of

Par Pond transects. June, July, September, and October 1995

Figure 12.

Comparison of predrawdown macrophyte percent cover

and bed width with 1995 percent cover and bed width 


\title{
Par Pond Vegetation Status Summer 1995-Summary
}

\author{
Halkard E. Mackey, Jr. and R. S. Riley \\ Westinghouse Savannah River Company \\ Savannah River Technology Center \\ Environmental Sciences Section \\ Aiken, SC 29808
}

\begin{abstract}
A survey of the newly emergent, shoreline aquatic plant communities of Par Pond began in June 1995, three months after the refilling of Par Pond to approximately 200 feet (61 meters) above mean sea level. The survey was repeated in July, September, and October 1995. Aquatic plant communities similar to predrawdown Par Pond communities are becoming reestablished. Emergent beds of maidencane (Panicum hemitomon), lotus (Nelumbo lutea), water lily (Nymphaea odorata), and watershield (Brasenia schreberi) are extensive and well developed. Cattail (Typha spp.) occurrence continued to increase through the summer, buf large beds common to Par Pond prior to the drawdown have not formed. Estimates from SPOT remote sensing satellite data indicated that as much as 297 acres ( 120 hectares) of emergent wetlands vegetation may have been present along the Par Pond shoreline by early October 1995. Future surveys are planned for the growing seasons of 1996 and 1997 , along with the evaluation of satellite data for mapping the areal extent of the macrophyte beds of Par Pond.
\end{abstract}

\section{Introduction}

Par Pond, a 2500-acre (1012-hectare) cooling water reservoir on the Savannah River Site (SRS), was created in 1958 by constructing an earthen dam across the upper reaches of the Lower Three Runs drainage system (Figure 1) (Wilde and Tilly 1985). Par Pond served as a recirculating, cooling water reservoir for R Reactor until 1963 and for P Reactor from 1961 until 1988. P Reactor operated approximately $70 \%$ of the time prior to 1988 . Nutrient-rich make-up water from the Savannah River was pumped into Par Pond to maintain a constant water level. During the summer months the temperature of the water entering Par Pond from Pond $\mathrm{C}$ ranged from 72 to $108^{\circ} \mathrm{F}\left(22\right.$ to $42^{\circ} \mathrm{C}$ ) (Jones et al. 1979). Maximum shoreline water temperatures in the vicinity of the hot dam ranged from 90 to $95^{\circ} \mathrm{F}\left(32\right.$ to $35^{\circ} \mathrm{C}$ ) (Liu et al. 1978). The thermal effluent cooled rapidly as it dispersed primarily through the southern half of the reservoir (Ezra and Tinney 1985). The north and west arms of Par
Pond had temperatures at or only slightly above typical lake temperatures for the region (Liu et al. 1978).

The water level of Par Pond remained relatively stable, fluctuating typically less than 0.5 foot $(0.15$ meter) in most years. Natural invasion of macrophytes in the lake and along the shoreline occurred over the 33-year history of the lake, until mid-1991, when Par Pond was lowered from 200 feet (61 meters) above mean sea level (MSL) to 181 feet (55 meters) above MSL in about a 2-month period. Lowering the water level was deemed necessary to protect downstream residents from possible dam failure suggested by subsidence on the downstream slope of the dam.

Prior to lowering in 1991, Par Pond was bordered by extensive beds of persistent and nonpersistent aquatic macrophytes. These beds often exceeded 66-131 feet (20-40 meters) in width and in several areas exceeded 328 feet (100 meters) in width. 


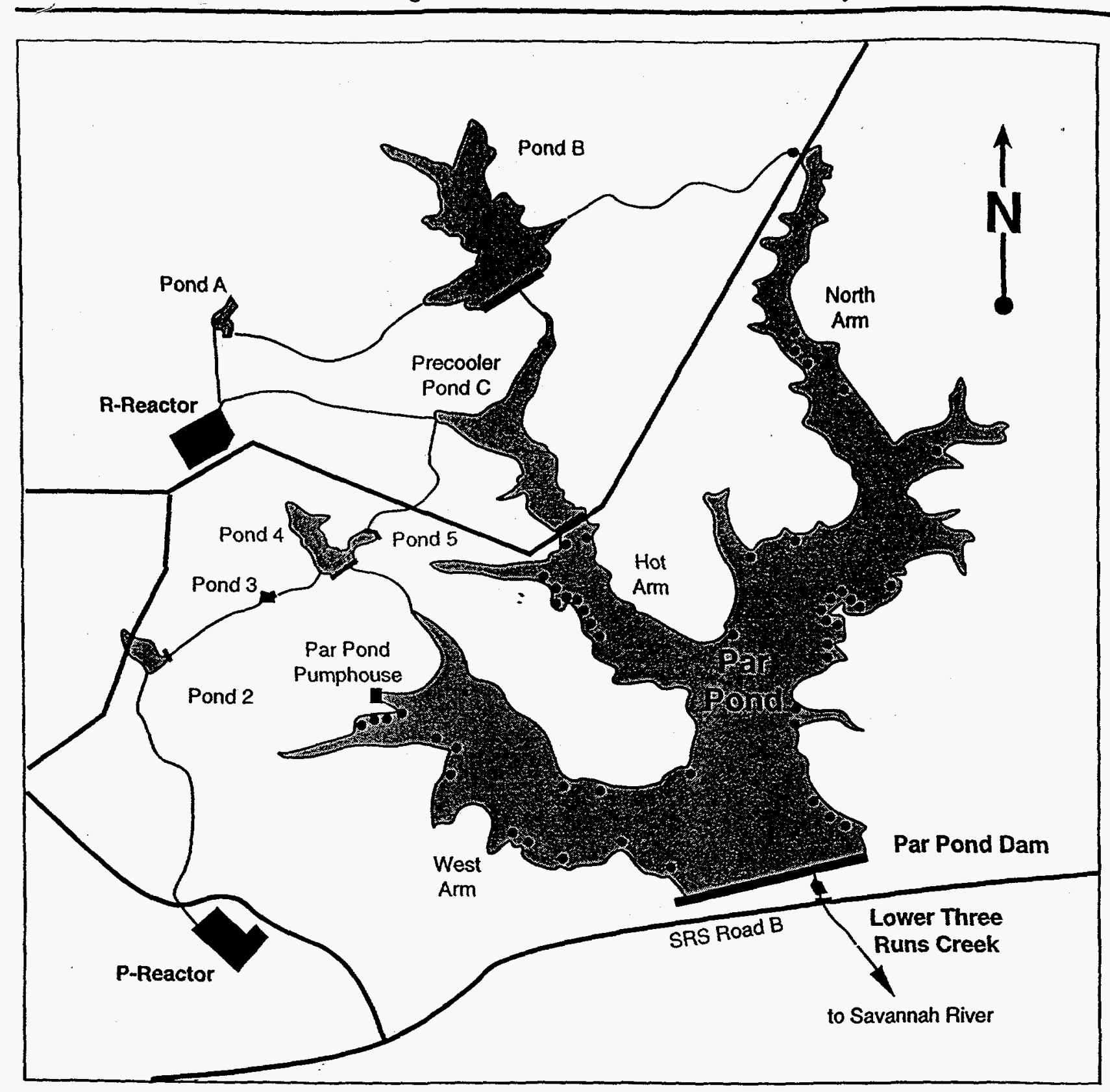

Figure 1. Map of Par Pond marked with locations of transects.

Estimates of cattails (Typha spp.) or persistent emergent macrophytes along the shoreline of Par Pond, using SPOT satellite data, were 474 acres (192 hectares) during the 1988 growing season, 442 acres (179 hectares) during 1989 , and 432 acres (175 hectares) during 1990. Estimates of water lilies (Nymphaea odorata) or other nonpersistent macrophytes were 371 acres (150 hectares) in 1988,311 acres (126 hectares) in 1989, and 368 acres (149 hectares) in 1990 (Jensen et al. 1993;
Narumalani 1993). Studies by Ezra and Tinney (1985) of airborne multispectral scanner data estimated that there were approximately 657 acres (266 hectares) of emergent macrophytes along the Par Pond shoreline in the fall of 1985.

In 1987, 62 transects were established along the shoreline of Par Pond (Jensen et al. 1991 a, 1991b, 1992a, 1992b, 1993; Jensen and Mackey 1991; Narumalani 1993). The dominant aquatic macro- 
phyte patterns were recorded each spring (April or May) and fall (September or October) from 1988 through June 1991, just prior to the lowering of the Par Pond water level. In these previous studies, the major species present in both the persistent (emergent, i.e., cattails) and nonpersistent (floating-leafed, i.e., water lily, lotus [Nelumbo lutea]) macrophyte categories were recorded, along with the width of each bed along the transects and estimates of percent cover by species at each transect. Spring and fall SPOT satellite data were also collected and analyzed for the 1988-1991 time period to provide estimates of area of coverage by major aquatic macrophyte category for the lake. These methods and data are summarized in the references above.

Baseline, vertical aerial, 9- by 9-inch format, falsecolor infrared photographs of Par Pond were taken on April 25, 1995 from an altitude of 10,000 feet. This photography was used as a general reference during the Par Pond surveys, even though little emergent vegetation is noticeable in the photographs, except in isolated coves or inlets to the lake.

Beginning in June 1991, Par Pond was lowered from 200 feet (61 meters) above MSL to 181 feet ( 55 meters) above MSL. This lowering was sufficient to expose both the emergent and nonemergent macrophyte beds of the Par Pond shoreline to drying conditions; therefore, extensive macrophyte losses occurred. Initial surveys in August 1992 by F. W. Whicker (Personal communication, Savannah River Ecology Laboratory) indicated some reinvasion on the newly exposed shoreline. Plant succession was occurring on about $65 \%$ of the exposed lake bed (newly exposed shoreline) with approximately $35 \%$ still barren. Grasses, sedges, and rushes were the dominant forms with a mixture of old-field species, including log-fennel ( $E u$ patorium sp.) and loblolly pine (Pinus taeda), which became more evident after spring 1993. In isolated pockets within coves of Par Pond, sufficient groundwater seepage or inflow from small streams allowed remnants of the Par Pond macrophyte communities to survive (e.g., beds of water lilies in the cove south of the Par Pond pump house [Figure 1]), as evident in late April 1995 vertical aerial photography. In mid-October 1994, after dam repairs were complete, the U.S. Department of Energy initiated the refill of Par Pond and by mid-March 1995 Par Pond water levels approached the level of the former full pool of approximately 200 feet (61 meters) above MSL (Figure 2). . The Par Pond water level has remained relatively constant since refill, fluctuating only about 0.6 foot (0.18 meter). (Figure 3).

\section{Methods}

Of the 62 transects established along the Par Pond shoreline in June 1991, 48 were relocated in March 1995. Descriptive notes on the vegetation patterns at each transect were taken in June 1995 to indicate the condition of any standing vegetation following refill and initial regrowth of macrophyte communities (Mackey and Riley 1995a, 1995b, 1995c, 1995d). Photographs of each transect were taken in June 1995. The transects were revisited and photographed in July 1995 . They were surveyed and photographed again in September 1995. A final survey was conducted in October 1995, and photographs were taken on October 27, 1995. Species present were recorded along with a nominal estimate of percent cover for any species appearing to occupy more than a "trace" (less than $0.1 \%$ ) of the water surface (Phillips 1959; MuellerDombois and Elienberg 1974). Two zones (an inner and outer zone) were characterized at each transect on each of the four surveys. Both zones started at the location pole of the transect marker that was used in the 1988-1991 surveys to mark the boundary between the persistent emergent aquatic beds (i.e., primarily cattails, spike-rush, [Eleocharis sp.]) and the nonpersistent, floatingleafed macrophyte beds (i.e., water lilies and lotus). The inner zone extended from the transect shoreward and the outer zone extended from the transect to deeper water. Water depth at the transect 


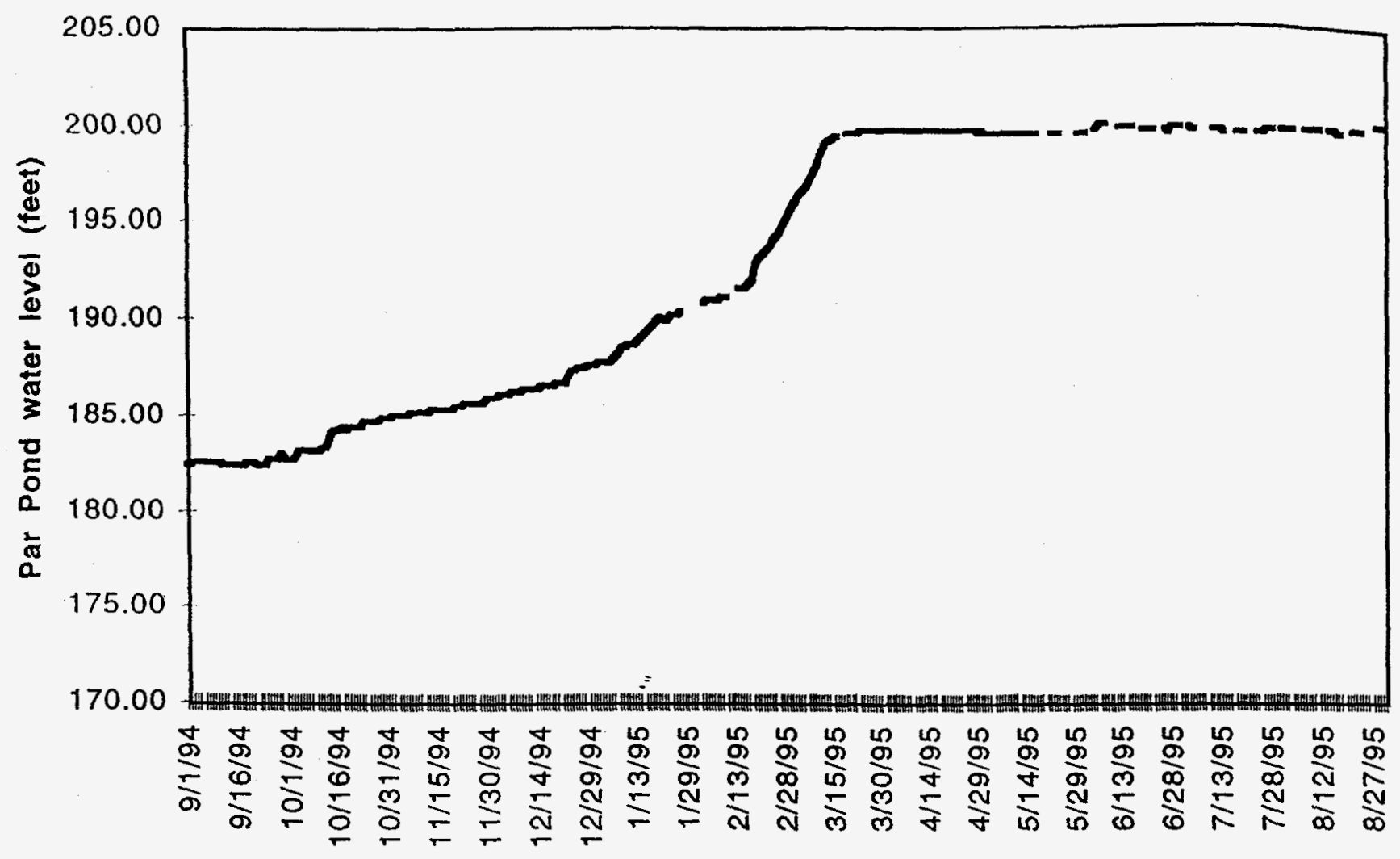

Figure 2. Rate of Par Pond refill during winter and early spring of 1995.

marker averaged approximately 3.3 feet ( 1 meter) in previous surveys (Jensen et al. 1991, 1992a, 1992b, and 1993; Jensen and Mackey 1991; Narumalani 1993). All transect pole locations were located to approximately 3 feet (1 meter) accuracy $(\mathrm{x}, \mathrm{y})$ with Global Position Survey equipment for future reference.

\section{Results}

Since the refilling of Par Pond, most of the oldfield species that had invaded much of the exposed shoreline are now absent. Dead dog fennel, broom sedge (Andropogon virginicus), poke berry (Phytolacca americana), briars (Rubus spp.), and other terrestrial plants were observed at the transects. Loblolly pines had grown in both the inner and outer transect zones and, except for those in the very shallow areas along the shoreline, have died (Figures 4 and 5). The most common woody species along Par Pond were newly invaded wil- low (Salix spp.) and red maple (Acer rubrum), but even these more flood-tolerant species are showing indications of stress and mortality as a result of the continued flooding over the past nine months (Figures 4 and 5). Extensive maidencane (Panicum hemitomon) beds were observed in both the inner and outer transect zones. The maidencane had undergone extensive stem elongation (Kirkman and Sharitz 1993) in areas of deeper water (more than 1.6 feet [0.5 meters]) and was the most common emergent macrophyte in $\mathrm{Par}$ Pond during the 1995 surveys.

The shoreline aquatic vegetation of $P$ ar Pond is undergoing rapid redevelopment. Figures 4-9 summarize estimates of percent occurrence (number of transects in which a species occurred divided by the total number of transects) and percent cover for the most common species observed at the transects during the 1995 surveys. Figures 10 and 11 show the changes in relative importance (per- 


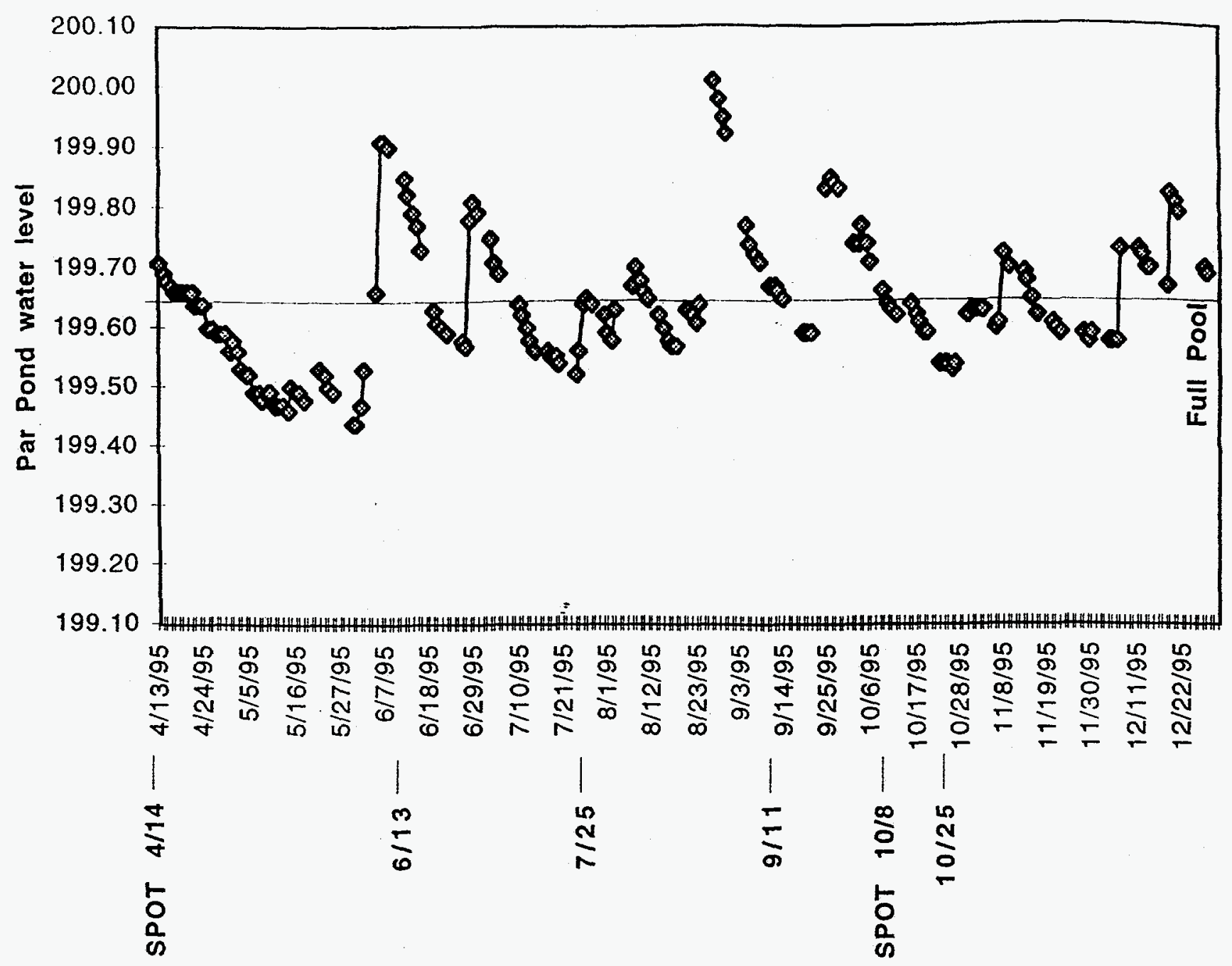

Figure 3. Water level changes following refill of Par Pond in 1995. Dates of SPOT satellite data collection and macrophyte surveys are indicated.

cent occurrence plus percent cover) in these macrophytes during the 1995 growing period. Maidencane's (the current dominant species along the shoreline of Par Pond) relative importance remained fairly constant from June to October (Figures 6-11). Other dominant species that occurred in Par Pond prior to the drawdown continue to increase in relative importance, especially lotus, water lily, watershield (Brasenia schreberi), and spike-rush. The increased occurrence of these speciess of macrophytes may represent widespread seed dispersion and availability from previous years. Cattails are present but remain widely scattered; no major beds had developed through late October. Small isolated beds of cattails (approximately 3 to 7 feet [ 1 to 2 meters] wide and 16 to 33 feet [5 to 10 meters] long) are forming along the original shoreline of Par Pond. However, most areas occupied by cattails prior to the drawdown continue to be dominated by maidencane or remain as open water with occasional lotus, water lily, and watershield present. The water level in Par Pond for the first seven months following refill has fluctuated about 0.6 foot $(0.2$ meter). This fluctuation may have permitted a small band of primrose (Ludwigia sp.) to develop along the shoreline of Par Pond in areas of exposed shoreline (Figure 10). A similar band was observed at L Lake for the first few years after it was filled in 1985. 


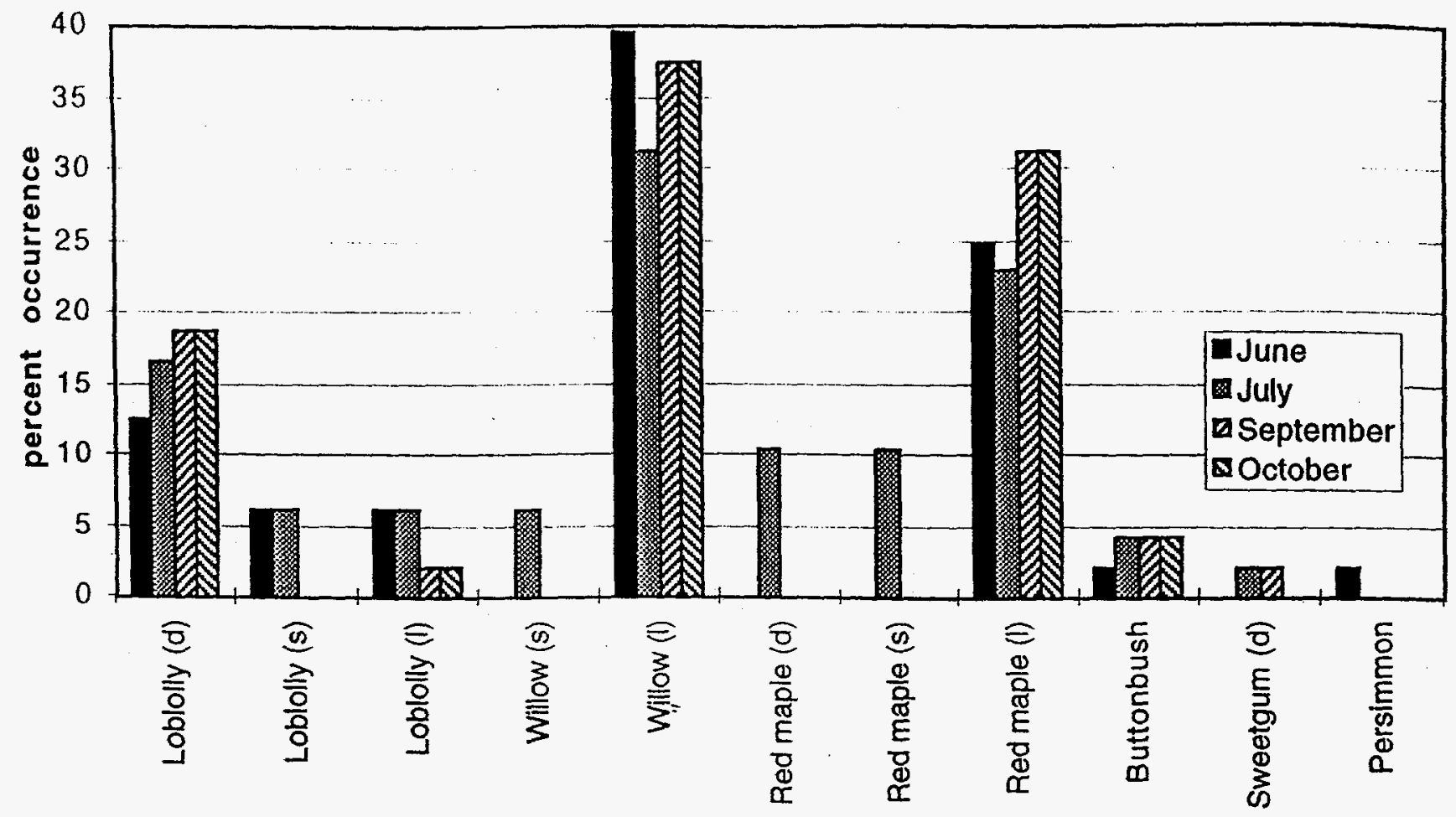

Figure 4. Woody species percent occurrence at the inner zones of Par Pond transects. [(I) = living; (s) = stressed; (d) + dead]. June, July, September, and October 1995.

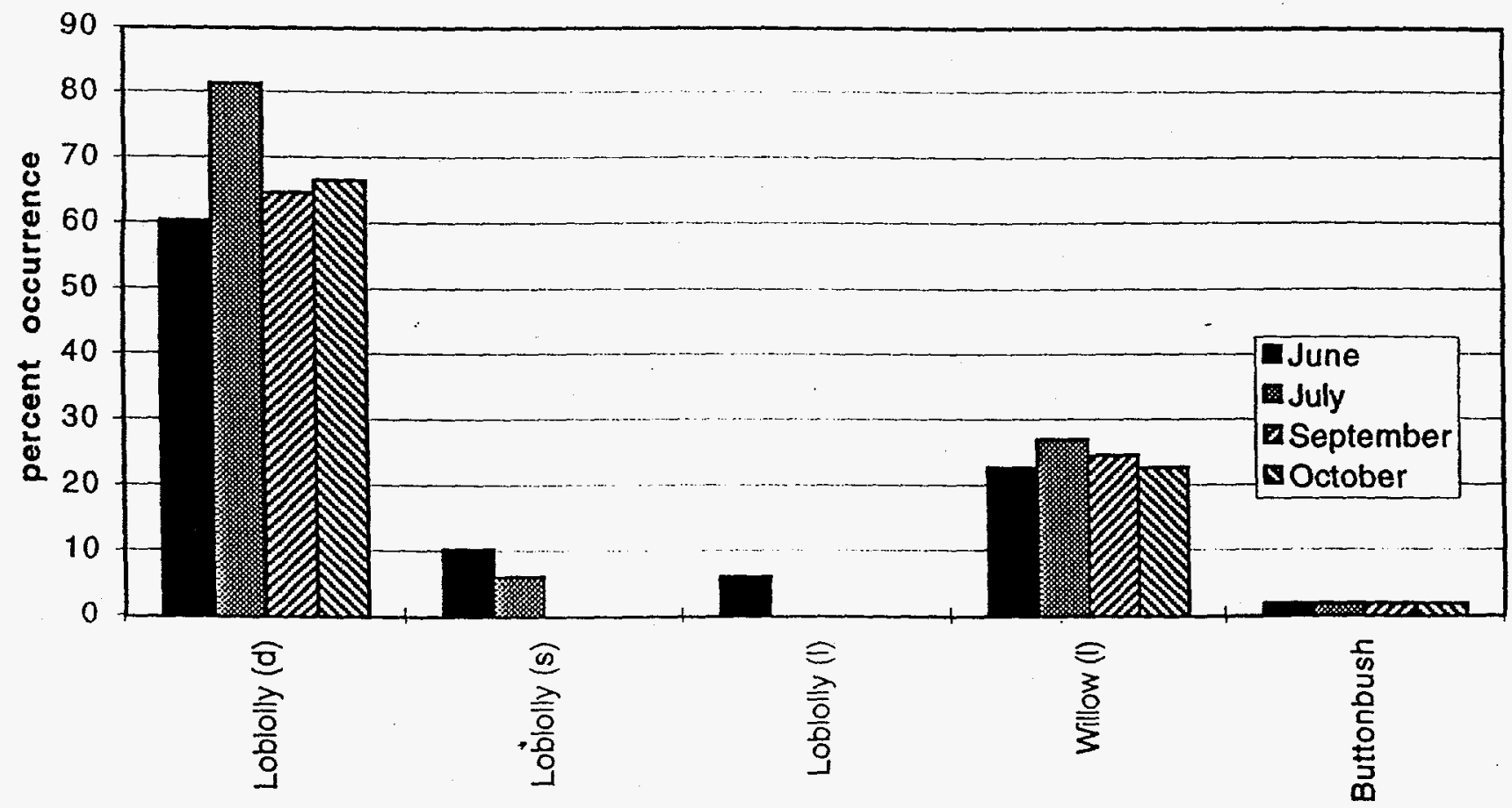

Figure 5. Woody species percent occurrence at the outer zones of Par Pond transects. $[(1)=$ living; $(s)$ = stressed; (d) = dead]. June, July, September, and October 1995. 


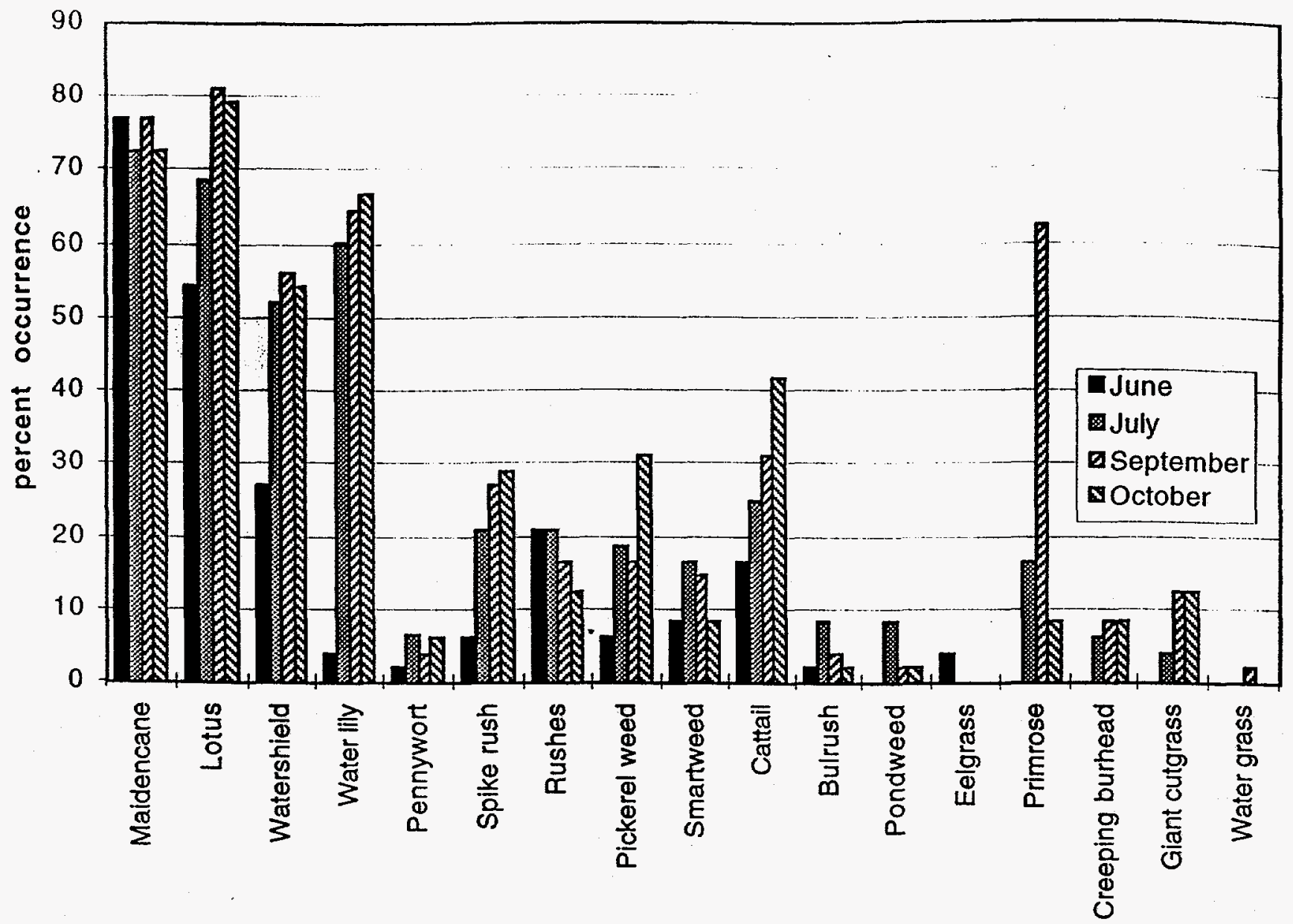

Figure 6. Herbaceous species percent occurrence at the inner zones of Par Pond transects. June, July, September, and October 1995.

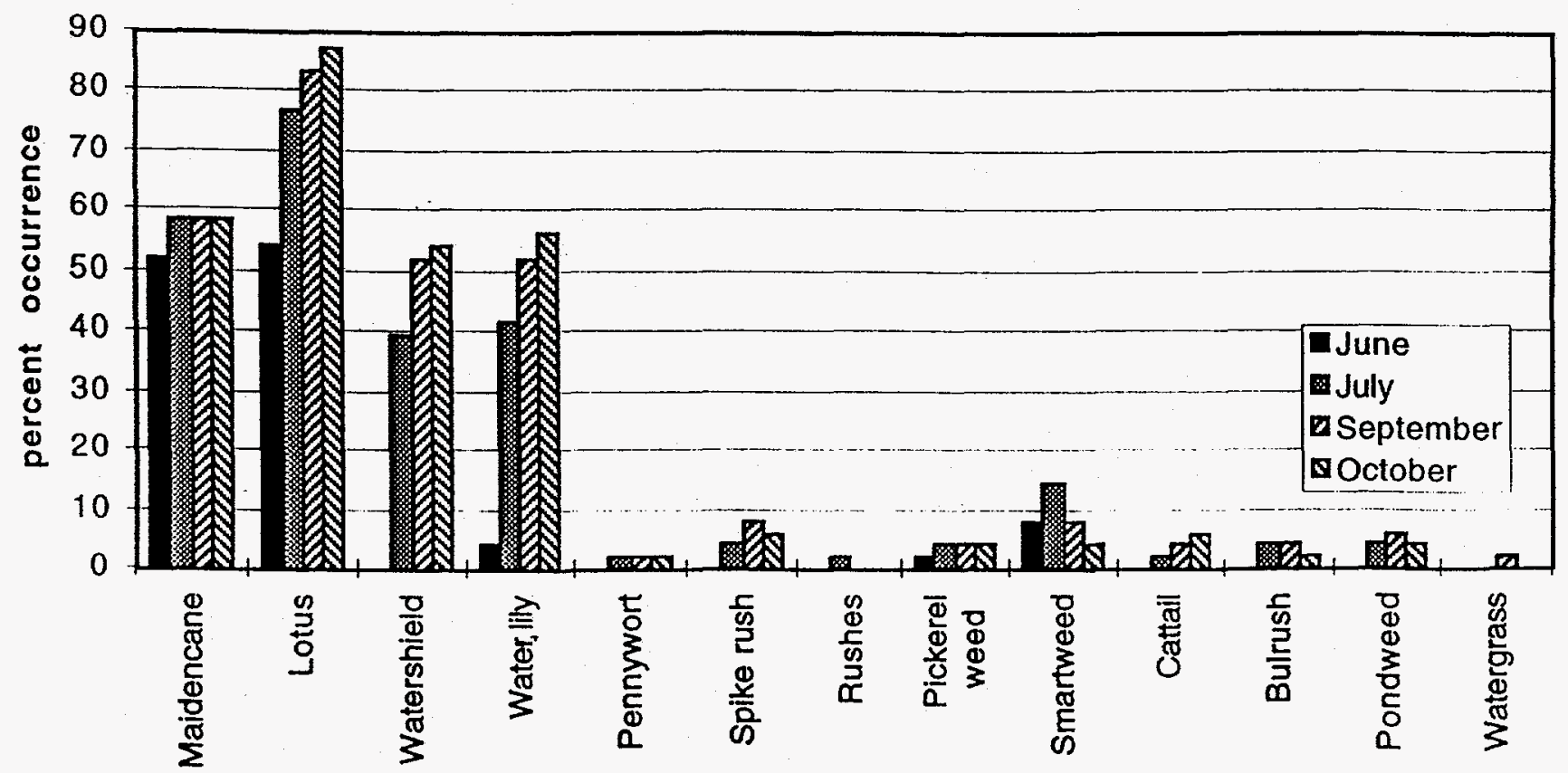

Figure 7. Herbaceous species percent occurrence at the outer zones of Par Pond transects. June, July, September, and October 1995. 


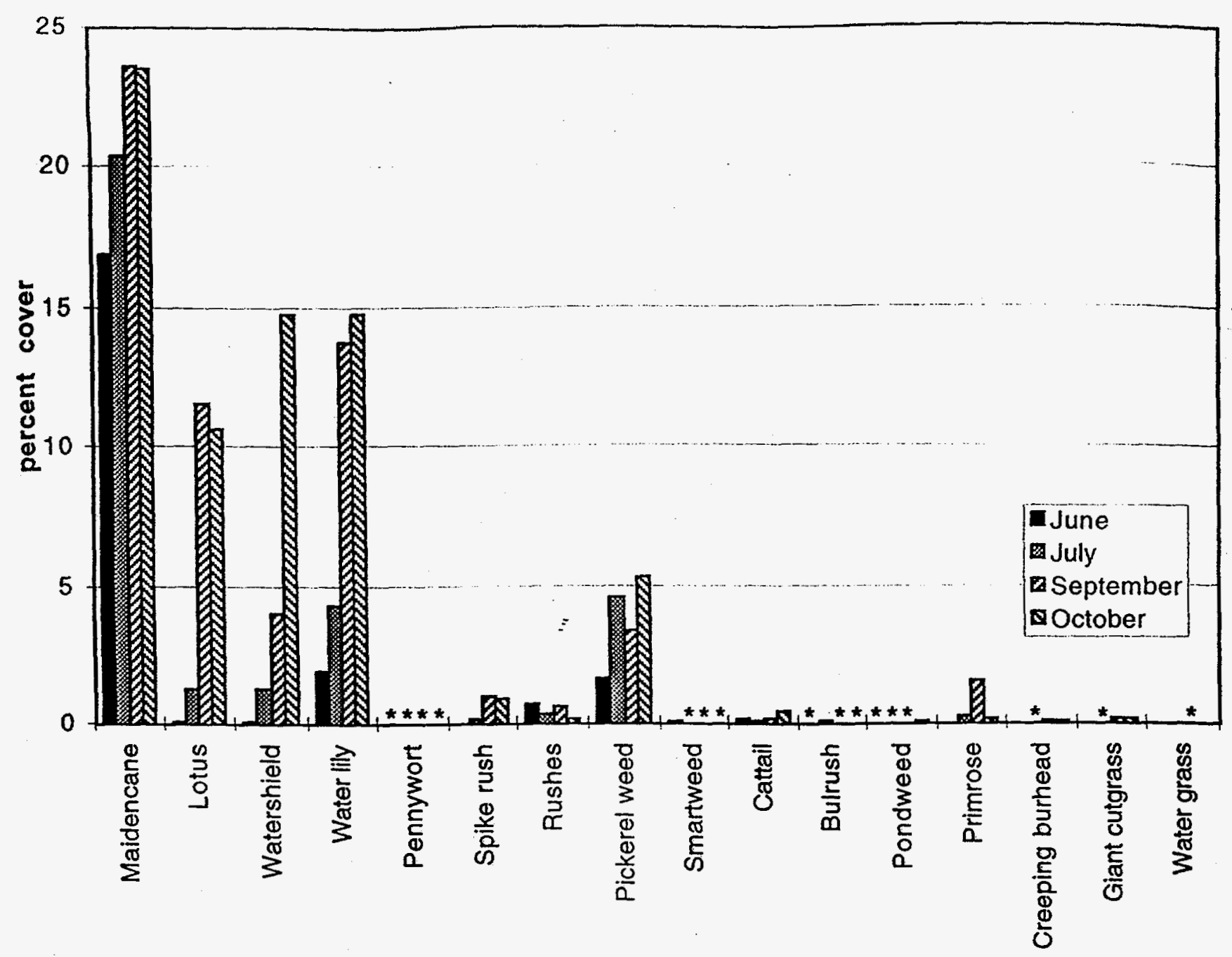

Figure 8. Herbaceous species percent cover at the inner zones of Par Pond transects. *Species present at less than 0.5 percent cover were pennywort in June, July, September, and October; smartweed in July, September, and October; bulrush in June, September, and October; pondweed in June, July, and September; creeping burhead in July; giant cutgrass in July; and water grass in September.

Figure 12 represents a comparison of macrophyte bed width and percent cover between 1988-1991 and 1995. The average percent cover for the 48 transects (outer zones only) was between 65-70\% for late 1989 and 1991; whereas in late 1995, the average percent cover for the outer zone of these same transects was approximately $45 \%$. For comparison purposes, consider that the planted emergent macrophytes in LLake had an average percent cover of $40 \%$ in 1989, two years after initial planting (Kroeger 1990). For a subset of 12 Par Pond transects that had high percent cover in 1995, the average width of the transects for $1988,1989,1990$, and 1995, averaged from 131 to 164 feet (40 to 50 meters).
In addition to the similarities of species composition and development trends, analyses of SPOT satellite data from April 1995 and early October 1995 were georegistered and compared for changes in macrophyte development using methods described in Jensen et al. (1991, 1992a, 1992b, 1993), Jensen and Mackey (1991), and Narumalani (1993). The data from April 1995 were acquired soon enough after the refill and early enough in the growing season to provide a baseline against which growth of new macrophyte beds could be compared. The SPOT data from April 1995 provided an estimate of 2455 acres ( 994 hectares) of open water for the surface area of Par Pond. This 


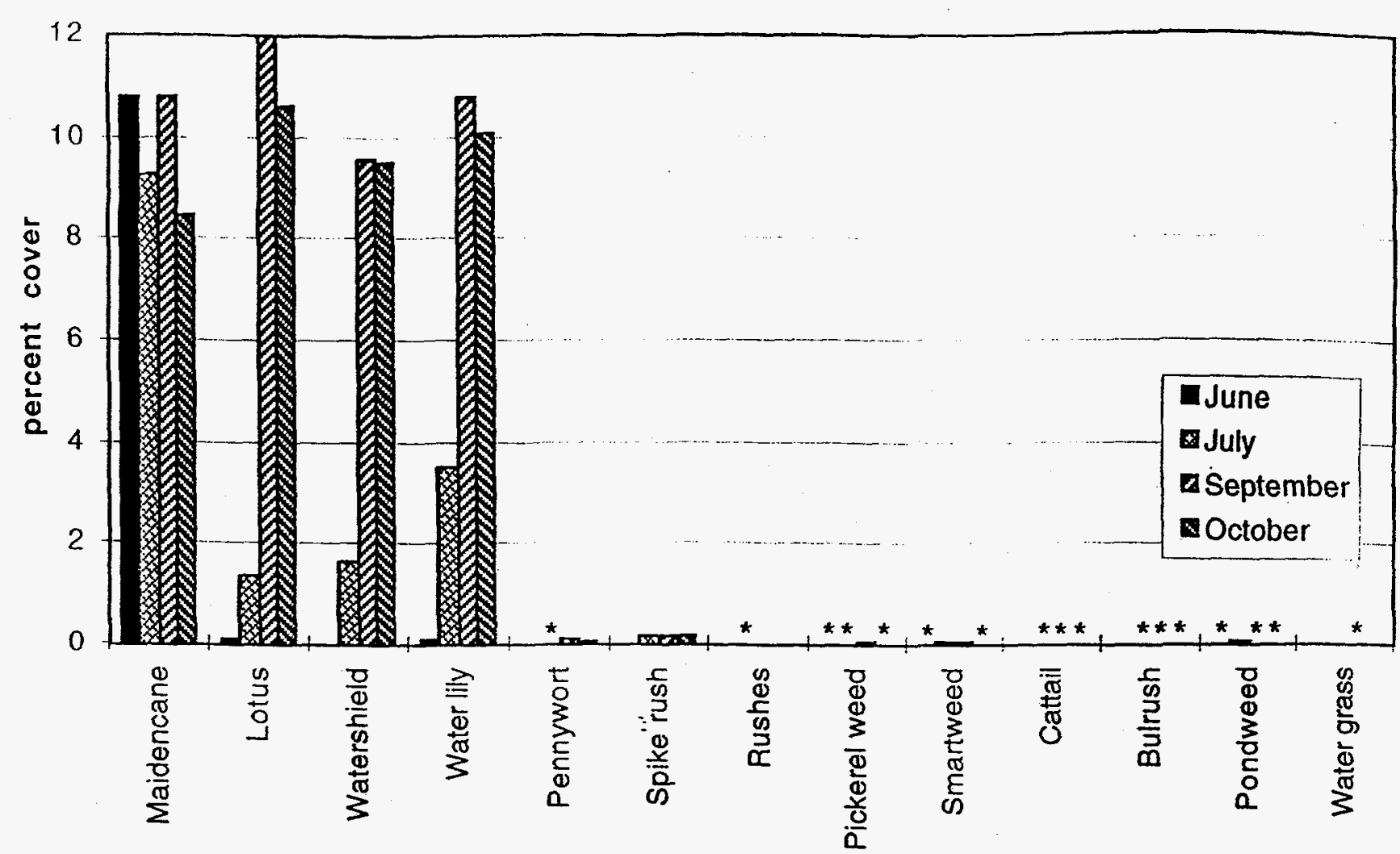

Figure 9. Herbaceous species percent cover at the outer zones of Par Pond transects. *Species present at less than 0.5 percent cover were pennywort in July; rushes in July; pickerel weed in June, July, and October; smartweed in June and October; cattail in July, September, and October; bulrush in July, September, and October; pondweed in June, September, and October; and water grass in September.

compares to an estimate of 2459 acres ( 995 hectares) of open water made by Ezra and Tinney (1985) with airborne multispectral scanner data, and estimates of approximately 2471 acres (1000 hectares) of open water by Jensen et al. (1993) and Wilde and Tilly (1985). Evaluation of the October 1995 SPOT data provided an estimate of 297 acres (120 hectares) of emergent macrophytes at the end of the growing season. Compare this estimate to 657 acres ( 266 hectares) estimated by Ezra and Tinney (1985) for September 1984 macrophyte cover, and to estimates of 845 acres ( 342 hectares) for 1988, 754 acres (305 hectares) for 1989, and 801 acres ( 324 hectares) for 1990 by Jensen et al. (1993) and Narumalani (1993). The relative dominance of the species of macrophytes has changed (more maidencane and less cattail), and the relative area of cover in 1995 after one growing season is about $40 \%$ of the cover estimated in years prior to drawdown.

\section{Discussion and Conclusions}

The shoreline aquatic vegetation of Par Pond is undergoing rapid redevelopment. Maidencane is currently the dominant species along the shoreline of Par Pond, and its percent cover and percent occurrence remained about the same from June 1995 to October 1995. Other dominant species that occurred in Par Pond prior to the drawdown continue to increase, especially lotus, water lily, watershield, and spike-rush. Cattails are present but remain widely scattered; no major beds have developed to date. Small isolated beds of cattails (approximately 3-7 feet [1-2 meters] wide and 16-33 feet [5-10 meters] long) are forming along the original shoreline of Par Pond. However, most areas occupied by cattails prior to the drawdown continue to be dominated by maidencane or remain as open water with occasional lotus, water lily, and watershield present. The water level in Par Pond for the first seven months 


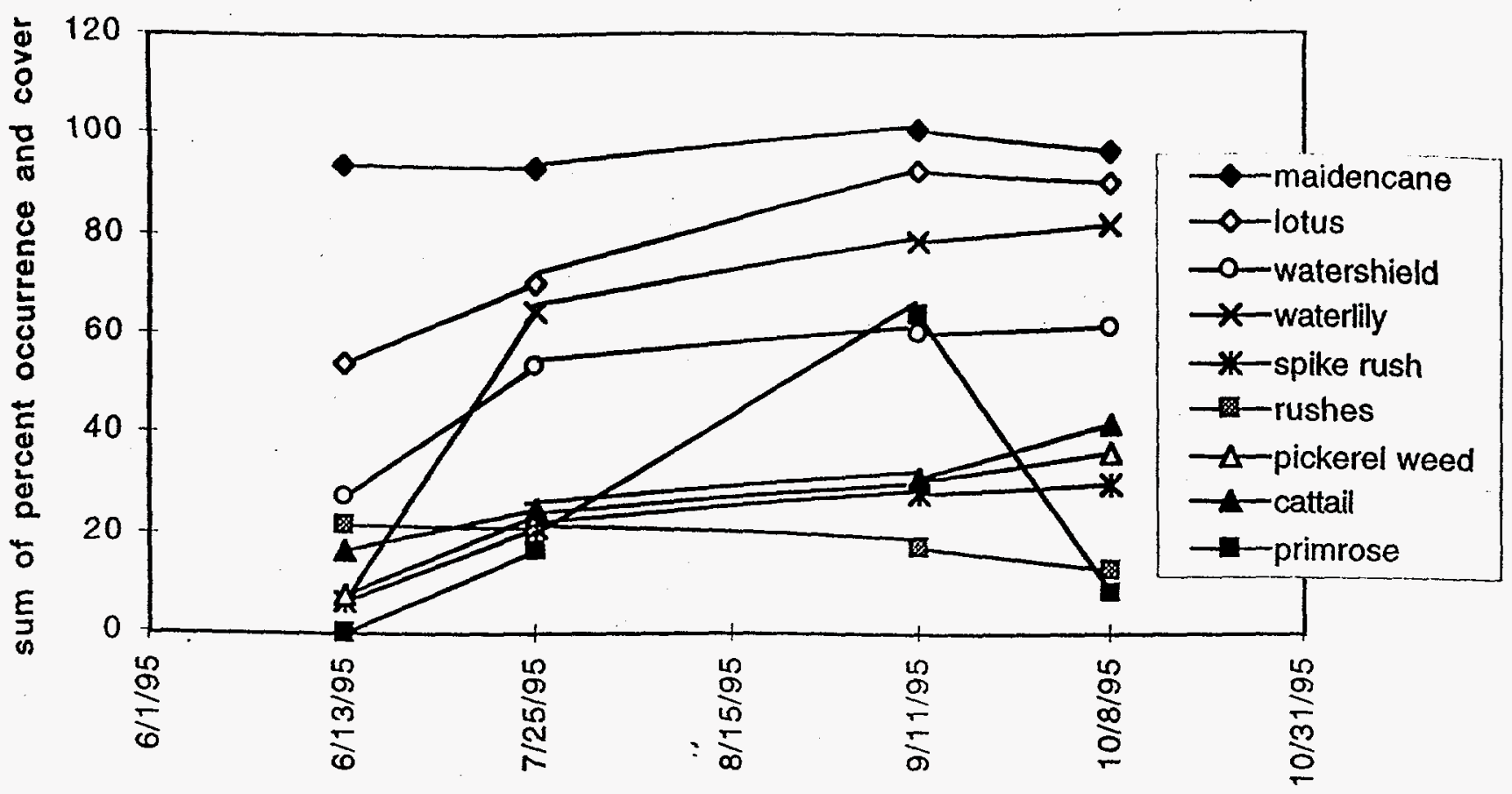

Figure 10. Trends in macrophyte growth at the inner zones of Par Pond transects. June, July, September, and October 1995.

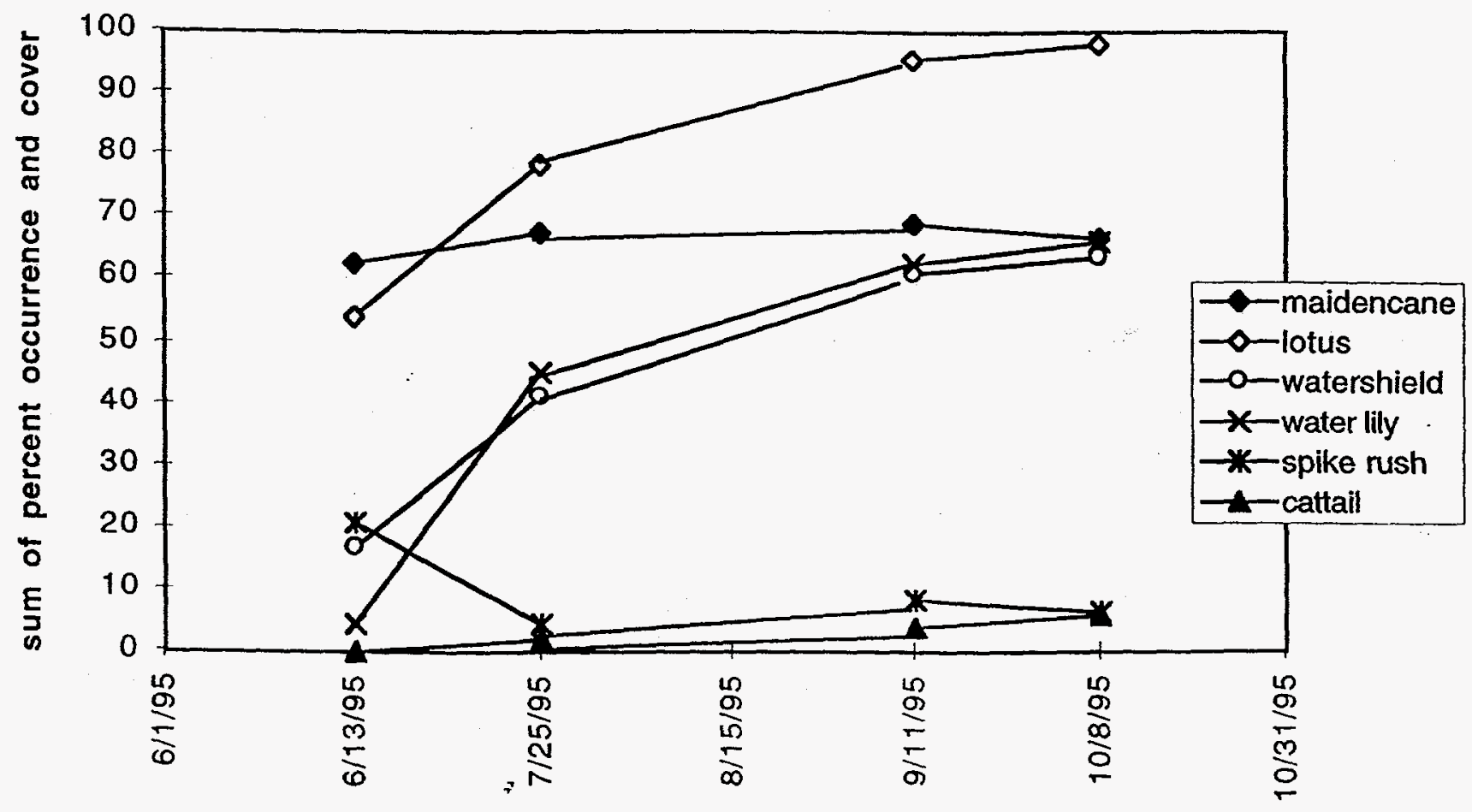

Figure 11. Trends in macrophyte growth at the outer zones of Par Pond transects. June, July, September, and October 1995. 


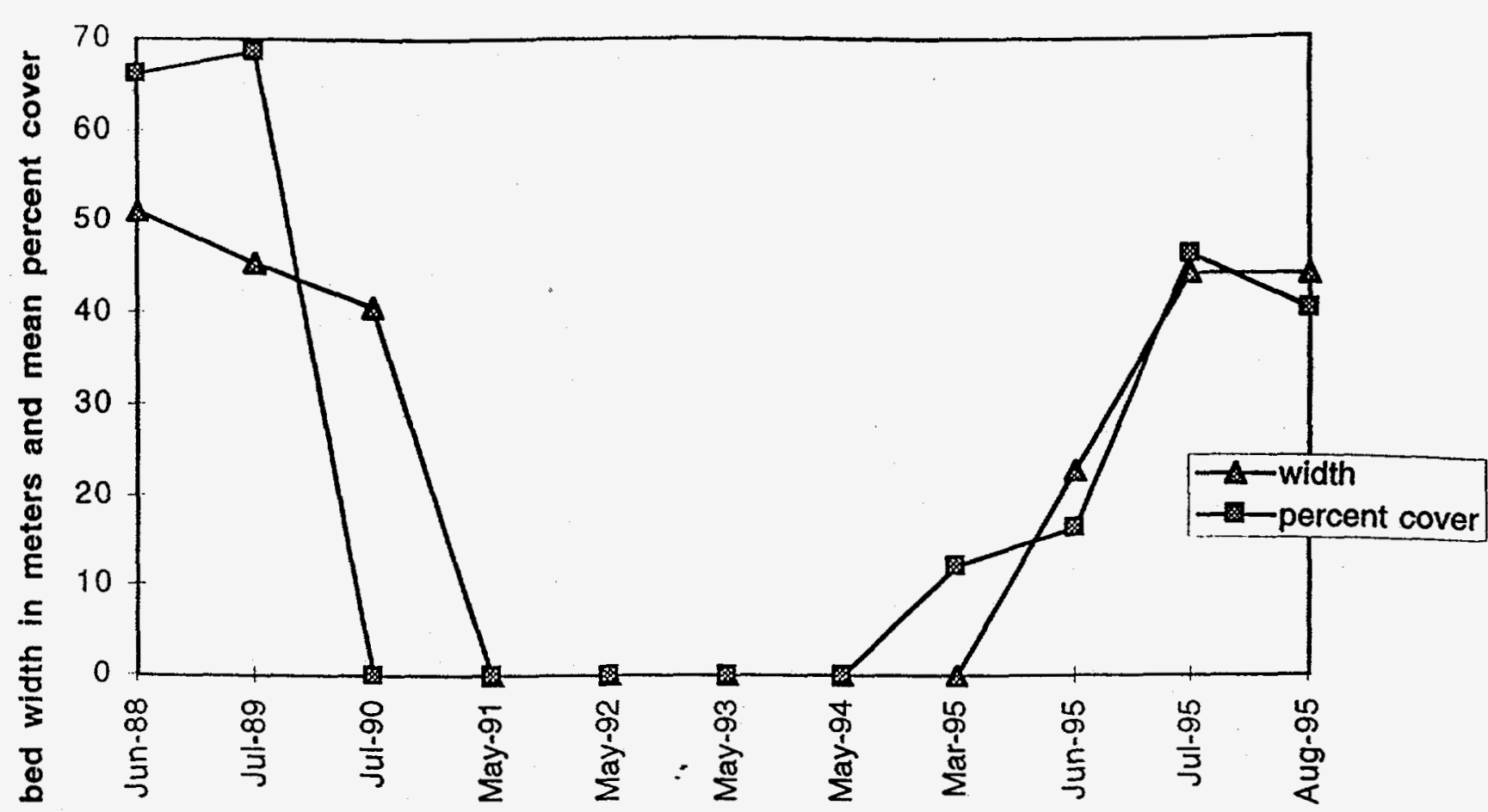

Figure 12. Comparison of pre-drawdown macrophytes percent cover and bed width with 1995 percent cover and bed width.

following refill has fluctuated about 0.6 foot $(0.2$ meter). This fluctuation may have permitted a small band of primrose (Ludwigia sp.) to develop along the shoreline of Par Pond in areas of exposed shoreline. A similar band was observed at L Lake for the first few years after it was filled in 1985 . The woody species such as loblolly pine, red maple, and willow are declining following the refill of $\mathrm{Par}$ Pond. These early surveys are already providing good evidence of the likely direction that the Par Pond communities will take in their development.

The exact composition of the final community types is speculative at this point. The water chemistry of Par Pond is likely to be more similar to Pond $B$ than it was during P Reactor operations unless Savannah River water is pumped into the reservoir. Thus, lotus and watershield are likely to become more common, and cattails are likely to become less common than in the past.

The water level of Par Pond may be allowed to fluctuate naturally as much as 3-7 feet (1-2 meters).
Plants inhabiting areas with fluctuating water levels are subject to a wide range of environmental conditions ranging from near drought to total inundation. Many wetland species can survive fluctuating hydrologic regimes and species' tolerances to the hydrologic extremes, as well as the timing of the fluctuations from year to year, will determine future community dominance patterns (Merendino and Smith 1991; Millar 1973).

Documentation of the relative performances and adaptive strategies of dominant plant species under different hydrological regimes is necessary to develop predictive models of community patterns in freshwater bodies. For example, Kirkman and Sharitz (1993) noted that maidencane survived inundation to 4 feet ( 1.2 meters) via stem elongation and had percent cover estimates as high as $30 \%$ in water depths to approximately 6 feet (1.8 meters). Maidencane flower production was observed under flooding conditions in that same study (Kirkman and Sharitz 1993). Apparently, the refilling of Par Pond during spring 1995 did not ex- 
ceed the possible rates of maidencane stem growth and elongation along much of the formerly exposed Par Pond shoreline. Kirkman and Sharitz (1993) postulated that increased dominance by maidencane occurs during periods of deep inundation during the growing season. Elongation of stems as a result of inundation during the growing season and prior to deepening winter water levels enables this species to survive greater depths of flooding in winter. However, if the dead stems of maidencane are lost during the winter, then areas of maidencane in deep water would not persist. Maidencane, with its dense root system and its ability to tolerate more acidic, lower-nutrient water and adjust to changes in water level, may prove to be a future dominant species on the Par Pond shoreline. If Savannah River water is no longer pumped to Par Pond, the reservoir is likely to become less nutrient-rich and more acidic, similar to lakes whose major source of input is groundwater. However, wave action in deeper, more open water areas of Par Pond may inhibit continued survival and growth of maidencane, especially if the overwintering stem biomass is lost (Kirkman and Sharitz 1993). Maidencane is also drought tolerant, suggesting that it probably will become more prominent in the plant community during natural drawdown or cycling of Par Pond lake levels (Kirkman and Sharitz 1993).

Species found in predrawdown macrophyte communities have become well established in all areas of Par Pond and are likely to survive any future natural water level fluctuations given the recovery and regeneration that occurred in a single growing season following nearly 4 years of a continuous 19-foot (6-meter) drawdown during which many macrophyte beds were eliminated and seed banks were exposed. Two to three years of surveys should provide good evidence of the likely direction that the Par Pond communities will take in their development. 


\section{References}

Ezra, C. E., and L. R. Tinney. 1985. Par Pond Macrophyte Study Savannah River Plant, Aiken, South Carolina. EG\&G/EM Letter Report DOE. (ONS-SRL) 8513.

Jensen, J. R., and H. E. Mackey, Jr. 1991. Remote Sensing of Freshwater Aquatic Macrophytes in a Southeastern Lake: Part 1-Analysis of 30 Years of Vertical Aerial Photography. Volume 3. Remote Sensing. Proceedings 1991 ACSM-ASPRS Annual Convention. Baltimore, MD. pp. 224-231.

Jensen, J. R., S. Narumalani, O. Weatherbee, and H. E. Mackey, Jr. 1991. Remote Sensing Offers an Alternative for Mapping Wetlands. Geo Info Systems. October 1991. pp. 48-53.

Jensen, J. R., S. Narumalani, O. Weatherbee, and H. E. Mackey, Jr. 1992a. Measurement of Seasonal and Yearly Macrophyte Changes in a Reservoir Using Multidate SPOT Panchromatic Data. Proceedings 1992 ACSM-ASPRS Annual Convention, Albuquerque, NM, pp. 167-176.

Jensen, J. R., S. Narumalani, O. Weatherbee, K. S. Morris, Jr., and H. E. Mackey, Jr. 1992b. Predictive Modeling of Cattail and Waterlily Distribution in a South Carolina Reservoir Using GIS. Photogrammetric Engineering \& Remote Sensing 58(11):1561-1568.

Jensen, J. R., S. Narumalani, O. Weatherbee, and H. E. Mackey, Jr. 1993. Measurement of Seasonal and Yearly Cattail and Waterlily Changes Using Multidate SPOT Panchromatic Data. Photogrammetric Engineering \& Remote Sensing 9(4):519-525.

Jones, J. C., J. F. Hancock, and E. H. Liu. 1979. Biochemical and Morphological Effects of Temperature on Typha latifolia L. (Typhaceae) Originating from Different Ends of a Thermal Gradient. I. Controlled Environmental Studies. American Journal of Botany 66(8):902-906.
Kirkman, L. K., and R. R. Sharitz. 1993. Growth in Controlled Water Regimes of Three Grasses Common in Freshwater Wetlands of the Southeastern USA. Aquatic Botany 44:345-359.

Kroeger, S. R. 1990. Wetland Vegetation Establishment in L-Lake. Report Number SREL-39. Savannah River Ecology Laboratory, University of Georgia, Savannah River Site, Aiken, SC.

Liu, E. H., R. R. Sharitz, and M. H. Smith. 1978. Thermal Sensitivities of Malate Dehydroganase Isozymes in Typha. American Journal of Botany $65(2): 214: 220$.

Mackey, H. E., Jr., and R. S. Riley. 1995a. Par Pond Vegetation Status Summer 1995-June Survey Descriptive Summary. WSRC-RP-95-0854, Westinghouse Savannah River Company, Aiken, SC.

Mackey, H. E., Jr., and R. S. Riley. 1995b. Par Pond Vegetation Status Summer 1995-July Survey Descriptive Summary. WSRC-RP-95-0720, Westinghouse Savannah River Company, Aiken, SC.

Mackey, H. E., Jr., and R. S. Riley. 1995c. Par Pond Vegetation Status Summer 1995-September Survey Descriptive Summary. WSRC-RP95-0891, Westinghouse Savannah River Company, Aiken, SC.

Mackey, H. E., Jr., and R. S. Riley. 1995d. Par Pond Vegetation Status Summer 1995-October Survey Descriptive Summary. WSRC-RP-951047, Westinghouse Savannah River Company, Aiken, SC.

Merandino, M. T. and L. M. Smith. 1991. Influence of Drawdown Date and Reflood Depth on Wetland Vegetation Establishment. Wildlife Society Bulletin. 19:143-150.

Millar, J. B. 1973. Vegetation Changes in Shallow Marsh Wetlands Under Improving Moisture Regime. Canadian Journal of Botany 51:1443-1457. 
Mueller-Dombois, D., and H. Ellenberg. 1974. Phillips, E. A. 1959. Methods of Vegetation Study. Aims and Methods of Vegetation Ecology. John Holt, Rinehart and Winston, Inc., New York, NY. Wiley \& Sons, Inc., New York, NY. 547 pp. $107 \mathrm{pp}$.

Narumalani, S. 1993. Classification and Modeling of Aquatic Macrophytes Using Remote Sensing and Geographic Information Systems. Ph.D. dissertation, Department of Geography, University of South Carolina, Columbia, SC. 105 pp.

Wilde, E. W., and L. J. Tilly. 1985. Influence of P. Reactor Operation on the Aquatic Ecology of Par Pond-A Literature Review. DP-1698, E. I. du Pont de Nemours and Company, Savannah River Laboratory, Aiken, SC. 


\section{Appendix A}

\section{Common and Scientific Names of Plants in this Report}

\begin{tabular}{llll} 
Common Name & Scientific Name & Common Name & Scientific Name \\
\hline bulrush & Scirpus sp. & pickerel weed & Pontederia cordata \\
button bush & Cephalanthus occidentalis & poke berry & Phytolacca americana \\
briars & Rubus spp. & pond weed & Potamogeton sp. \\
broom sedge & Andropogon virginicus & primrose. & Ludwigia sp. \\
cattail & Typha spp. & red maple & Acer rubrum \\
creeping burhead & Echinodorus sp. & rush & Juncus spp. \\
dog fennel & Eupatorium sp. & smartweed & Polygonum sp. \\
eelgrass & Vallisneria sp. & spike-rush & Eleocharis sp. \\
giant cutgrass & Zizaniopsis sp. & sweetgum & Liquidambar styraciflua \\
loblolly pine & Pinus taeda & water grass & Hydrochioa sp. \\
lotus & Nelumbo lutea & water lily & Nymphaea odorata \\
maidencane & Panicum hemitomon & watershield & Brasenia schreberi \\
pennywort & Hydroctyle sp. & willow & Salix sp. \\
persimmon & Diospyros virginiana & &
\end{tabular}

